\title{
THE RELATIONSHIP BETWEEN WORKLOAD AND MOTIVATION WITH HEALTH WORKER'S PERFORMANCE IN COMMUNICABLE DISEASE PROGRAM IN PRIMARY HEALTH CENTRE IN EAST KOLAKA DISTRICT
}

\author{
Muh.Said ${ }^{1}$, La Ode Saafi ${ }^{2}$, Sunarsih ${ }^{3}$ \\ ${ }^{1,2,3}$ Magister of Public Health Study Program, College of Health Sciences Mandala Waluya \\ Kendari, Southeast Sulawesi, Indonesia
}

Corresponding Author : Muh.Said

Email : muhamadsaid781229@gmail.com

\section{Abstract}

Background: The incidence of infectious diseases in the world, Indonesia and provinces is still relatively high. Based on WHO data (2017), the top ten diseases that cause death are under 5 years of age, including HIV / AIDS 4\%, diarrhea $18 \%$, measles $1 \%$, malaria $8 \%$, pneumonia $16 \%$, premature $12 \%$, birth asphyxia $9 \%$., neonatal sepsis $6 \%$, congenital abnormalities $4 \%$, and accident 3\%. In Indonesia, the incidence of infectious diseases is still high and some have experienced an increase in cases from the previous year. The data from the East Kolaka Health Service Profile shows that Accute Respiratory Infection (ARI) has increased by 55\%, the number of sufferers is 84 , while diarrheal disease has increased by $24 \%$, the number of sufferers is 839, and TB disease has increased by $65 \%$ The number of patients 129 .

Methods: This type of research is a cross sectional study. The population of this study were all programmers in the working area of the East Kolaka Health Service as many as 48 programmers. The sampling technique was carried out by simple random sampling using the Lemeshow formula. Data were collected through a questionnaire and then analyzed using the Chi Square test.

Result: The results showed that chi square of motivation $=5.773$ and workload $=8,644$. They chi squar etable is 3,841 at $\alpha=5 \%$ and $\mathrm{df}=1$. It means that chi square value $>$ chi square table.

Conclusion: There was a relationship between motivation, and workload with performance of officers in East Kolaka Regency.

Key words: Performance, workload, motivation, health worker. 


\section{INTRODUCTION}

Infectious disease is a disease that is transmitted from a person, animal, or source of inanimate objects to another person either directly, with the help of vectors or by other means(1). Several types of infectious diseases such as pulmonary tuberculosis, dengue fever, and diarrhea have several similarities in physical environmental factors (altitude and rainfall), socio-economic environment (family category, population density, and occupant density), and hosts (age, sex, and behavior)(2).

The study of World Health Organization (WHO) in 1995 reported that pulmonary diseases or Tuberculosis (TB) was endemic with an estimated 9 million cases / year(3). Currently in Asia, including India, China, Indonesia, Bangladesh, Philippines and Pakistan. There are 4.5 million cases means more than half of Tuberculosis (TB) cases in the world. In 1993 WHO designated pulmonary TB as The Global Emergency because in most countries in the world, TB disease was out of control(4).

The incidence of infectious diseases in the world, Indonesia, and provinces is still high(5). The results of a study by Saomi et.al, 2015 in the Ex Residency of Pati regarding the factors that influence the case finding of pulmonary tuberculosis have an interest in becoming a TB officer. Officers feel that their duties and responsibilities as implementing TB program officers have high risks and heavy burdens(6).

Diarrheal disease is an endemic disease in Indonesia and is also a potential outbreak that often results in death, Southeast Sulawesi is no exception(7). Based on the results of the 2015 Riskesdas, the prevalence of diarrhea in Southeast Sulawesi was 7.3\% with the incidence of diarrhea in children under five around 5\%. The number of diarrhea cases handled in 2018 was 39,913 cases or $53.72 \%$ of the estimated cases, higher than in 2017 of 35,864 cases $(46.77 \%$ of the estimated cases)(8).
From the data from the profile of the East Kolaka Health Office, ARI disease has increased by $55 \%$, the number of patients is 84 , while diarrhea has increased by $24 \%$, the number of sufferers is 839 , and TB disease has increased by $65 \%$ for the number of 129 sufferers. it requires the performance of all health personnel in the primary health centre, especially those specifically in the infectious disease control program unit $(\mathrm{P} 2 \mathrm{M})$ in an effort to reduce the incidence of ARI, diarrhea and TB in the working area of the East Kolaka Health Office. ARI and TB are always included in the list of the top ten largest diseases in the working area of the East Kolaka Health Office, from these data it is necessary to increase the performance or role of officers(9).

\section{METHOD}

This type of research is a quantitative study using cross sectional study design(10). The population of this study was all programmers in the working area of the East Kolaka Health Service as many as 48 programmers. While a sample of 33 respondents. The samples in this study conducted by random sampling. The sampling technique carried out by simple random sampling using the Lemeshow formula(11). Data were collected through a questionnaire and then analyzed using the Chi Square test(12).

\section{RESULT}

Table 1 shows that out of 16 health workers who have low motivation, there are $87.5 \%$ whose performance does not meet and $16 \%$ of workers whose performance meets. Meanwhile, of the 17 respondents who had high motivation, there were $41.2 \%$ whose performance did not meet and $58.8 \%$ of the officers whose performance was satisfactory. Based on the results of statistical tests using the chi-square test obtained $\mathrm{X} 2$ count $>\mathrm{X} 2$ table $(5.773>3.841)$ at $\alpha 0.05 \mathrm{df}=1$. This means that there is a relationship between compensation and performance of officers in East Kolaka Regency. The results of the 
relationship closeness test show the Phi $(\Phi)$ coefficient of 0.481 , this shows the strength of the relationship between motivation and performance of officers in East Kolaka Regency in the medium relationship category.

Table 1

Relationship between Motivation and Officer Performance

\begin{tabular}{|c|c|c|c|c|c|c|c|}
\hline \multirow{3}{*}{ Motivation } & \multicolumn{4}{|c|}{ Officer Performance } & \multirow{2}{*}{\multicolumn{2}{|c|}{ Total }} & \multirow{2}{*}{ Statistic test } \\
\hline & \multicolumn{2}{|c|}{ Does not meet the } & \multicolumn{2}{|c|}{ Fulfill } & & & \\
\hline & $\mathbf{f}$ & $\%$ & f & $\%$ & $\mathbf{f}$ & $\%$ & $\mathrm{X} 2$ hit $=5.773$ \\
\hline Low & 14 & 87.5 & 2 & 12.5 & 16 & 100 & $\mathrm{X} 2 \mathrm{tab}=3,841$ \\
\hline High & 7 & 41.2 & 10 & 58.8 & 17 & 100 & $\mathrm{p}$ value $=0.016$ \\
\hline Total & 21 & 63.6 & 12 & 36.4 & 33 & 100 & phi $=0.481$ \\
\hline
\end{tabular}

Table 2 shows that of the 18 health workers who have a light workload, there are $88.9 \%$ whose performance does not meet and $11.1 \%$ of workers whose performance is satisfactory. Meanwhile, of the 15 respondents who had a heavy workload, there were $33.3 \%$ whose performance did not meet and $66.7 \%$ of the officers whose performance was satisfactory. Based on the results of statistical tests using the chi-square test obtained X2 count> X2 table $(8,644>$ $3,841)$ at $\alpha 0.05 \mathrm{df}=1$. This means that there is a relationship between workload and the performance of officers in East Kolaka Regency. The results of the relationship closeness test show the Pi coefficient $(\Phi)$ of 0.481 , this shows the strength of the relationship between compensation and performance of officers in East Kolaka Regency, in the strong relationship category.

Table 2

Relationship between Workload and Officer Performance

\begin{tabular}{l|c|c|c|c|c|c|l}
\hline \multirow{2}{*}{ Workload } & \multicolumn{4}{|c|}{ Officer Performance } & \multicolumn{2}{|c|}{ Total } & \multirow{2}{*}{ Statistic test } \\
\cline { 2 - 6 } & Does not meet the & \multicolumn{2}{|c|}{ Fulfill } & \multicolumn{2}{|c}{} \\
\cline { 2 - 6 } & f & $\mathbf{\%}$ & $\mathbf{f}$ & $\mathbf{\%}$ & $\mathbf{f}$ & $\mathbf{\%}$ & X2hit $=8,644$ \\
\hline Light & 16 & 88.9 & 2 & 11.1 & 18 & 100 & X2tab $=3,841$ \\
\hline Weight & 5 & 33.3 & 10 & 66.7 & 15 & 100 & $\begin{array}{l}\text { p value }=0.003 \\
\text { phi }=0.575\end{array}$ \\
\hline Total & 21 & 63.6 & 12 & 36.4 & 33 & 100 & \\
\hline
\end{tabular}

\section{DISCUSSION}

\section{Relationship between Motivation and Infectious Disease Staff's Performance}

Motivation is a series of attitudes and values that influence individuals to achieve specific things in accordance with individual goals(13). These attitudes and values are an invisible impetus that provides the strength to encourage the individual to behave in achieving goals(14).

Based on research that has been done on 33 Infectious disease officers in East Kolaka Regency regarding work motivation, it is known that there is a relationship between motivation and the performance of officers. The strength of this relationship is in the medium category. These results can be explained that, employees who have high motivation will have a high responsibility to work enthusiastically and as well as possible, mobilizing all abilities and skills in order to achieve optimal performance. Good employee performance will be achieved if employees have high motivation to work.

The results of this study are in line with research by Sulastriningsih (2016) which shows that there is a positive effect of motivation of health workers on the performance of health workers in implementing IMCI(15). In addition, from 
the results of Octavariny's (2018) research, it is concluded that there is a close relationship between both intrinsic and extrinsic work motivation obtained by KIA officers and the resulting performance in carrying out their duties as MCH officers(16).

\section{Relationship between Workload and Communicable Disease Staff's Performance}

Workload is a group or a number of activities that must be completed by an organizational unit or an office holder within a certain period of time(17). Workload is the main parameter that companies must pay attention to in an effort to improve employee performance. The workload of the appropriate employee will provide a high performance output(18).

Based on research that has been done on 33 Infectious disease officers in East Kolaka Regency regarding workload, it is known that there is a relationship between workload and officer's performance. The strength of this relationship is categorized as strong. Workload is a number of tasks that must be completed within a certain time. Workload for infectious disease officers is influenced by their function to carry out their duties and capacities to perform these functions. The workload of an infectious disease worker can be calculated from the effective time spent completing the tasks that become their burden. So that in their capacity as an infectious disease officer who carries out their duties and functions as well as the time that has been used.

This research is in line with Mulyasih (2019) that workload has a unidirectional level of relationship to nursing performances, if there is an increase in workload it will affect nursing performance(19). In addition, the results of this study are in accordance with the research of Arifuddin (2015) which states that workload affects performance. This is because this excessive workload greatly affects the productivity of health workers and of course affects the productivity of the hospital itself(20).

\section{CONCLUSION}

The conclusions in this study that there is a correlation between motivation with performance of officers in East Kolaka Regency. The results of the closeness test show the strength of the relationship between motivation and performance of officers in East Kolaka Regency in the medium relationship category. Apart from motivation, workload also has a relationship with the performance of officers in East Kolaka Regency. The closeness test results show the strength of the relationship between workload and the performance of officers in East Kolaka Regency in the strong relationship category.

\section{REFERENCES}

1. Setiyabudi R. Systematic review : Factors related to malaria as communcable diseases in Indonesia. Medisains. 2016;14(1) (Indonesia).

2. Khayra A. Communicable diseases. 2020.

3. WHO. World health statistics 2016: monitoring health for the SDGs sustainable development goals: World Health Organization; 2016.

4. WHO. The end TB strategy. World Health Organization, 2015.

5. Dharmayanti I, Tjandararini DH. Identify of indicator indexa in public health development to increase communicable disease index. Jurnal Keperawatan Padjadjaran. 2018;5(3) (Indonesia).

6. Saomi EE, Cahyati WH, Indarjo S. Relationship between individual characteristic with lung tuberculosis in Ex-Karesidenan Pati in 2013. Unnes Journal of Public Health. 2015;4(1) (ndonesia).

7. Office SSH. Health Profile of Southeast Sulawesi Province. In: 
Office SSH, editor. Kendari: Southeast Sulawesi Health Office; 2017.

8. Amaliah R, Maria IL, Maidin MA, editors. Surveilance staff performance of Kusta in all of primary health centre in Jeneponto in 2016. Jurnal Forum Kesehatan; 2017 (Indonesia).

9. Office EKH. Profile of the East Kolaka Health Office. In: Office EKH, editor. East Kolaka: East Kolaka Health Office; 2019 (Indonesia).

10. Yusuf AM. Research Metode of qualitative, quantitative and mix methods: Prenada Media; 2016 (Indonesia).

11. Asra A, Prasetyo A. Sampling technique in Survey research Edisi Perdana, PT Raja Grafindo Persada, Jakarta. 2015 (Indonesia).

12. Prsetyo B, Jannah LM. Quantitative research metode. 2019 (Indonesia).

13. Herzberg F. Motivation to work: Routledge; 2017.

14. Saraswati PS. Correlation Of Supervision, Opportunities For Advancement And Job Safety With Satisfaction Of health centre Employees In North Konawe District: English. Indonesian Journal Of Health Sciences Research And Development (Ijhsrd). 2019;1(1):9-21 (Indonesia).

15. Akbar, M.I., W.O.N.N. Rachman, and S. Risky, Factors Relating To The Performance Of Health Workers In Abeli City Health Center, Kendari City: Performance Of Health Workers. Indonesian Journal Of Health Sciences Research And Development (IJHSRD), 2020. 2(1): p. 9-14 (Indonesia).

16. Octavariny R, Sinaga SIS. Relationship between health operational budged and Motivation with mother and child program performance. Jurnal Penelitian Kesmasy. 2018;1(1):27-30 (Indonesia).

17. Ratnasari S, Lestari L. Effect of Leadership Style, Workload, Job Insecurity on Turnover Intention. International Journal of Innovation,
Creativity
and
Change. 2020;10(2):2201-1315.

18. Hancock PA, Matthews G. Workload and performance: Associations, insensitivities, and dissociations. Human factors. 2019;61(3):374-92.

19. Mulyasih I, Sulistiadi W, Sjaaf SA. Analysis of the relationship between workload and productivity with nursing performance in Banten Hospital. Jurnal Bidang Ilmu Kesehatan. 2019;9(1):7-23 (Indonesia).

20. Arifuddin A, Napirah MR. The relationship between discipline and workload with Nurse performance in Undata Palu Hospital. Healthy Tadulako Journal (Jurnal Kesehatan Tadulako). 2015;1(1) (Indonesia). 